\title{
Expression of colSR Genes Increased in the $r p f$ Mutants of Xanthomonas oryzae pv. oryzae KACC10859
}

\author{
Young-Hee Noh ${ }^{1}$, Sun-Young Kim ${ }^{2}$, Jong-Woo Han ${ }^{3}$, Young-Su Seo ${ }^{2}$ and Jae-Soon Cha ${ }^{*}$ \\ ${ }^{1}$ Department of Plant Medicine, Chungbuk National University, Cheongju, Chungbuk 361-763, Korea \\ ${ }^{2}$ Department of Microbiology, Pusan National University, Busan 609-735, Korea \\ ${ }^{3}$ Watermelon Research Institute, Chungbuk ARES, Cheongwon, Chungbuk 363-883, Korea
}

(Received on December 29, 2013; Revised on May 25, 2014; Accepted on May 25, 2014)

The $r p f$ genes and $c o l S_{\mathrm{xOO1207}} / \mathrm{col} R_{\mathrm{XoO1208}}$ were known to require for virulence of Xanthomonas oryzae pv. oryzae (Xoo). In Xoo KACC10331 genome, two more cols/ colR genes, $\operatorname{col} S_{\mathrm{X} 003534}(\mathrm{raxH}) / \operatorname{col} R_{\mathrm{X} 003535}(\operatorname{raxR})$ and $\operatorname{col} S_{\mathrm{XO03762}} / \operatorname{col}_{\mathrm{X}_{\mathrm{X} 003763}}$ were annotated. The $\operatorname{col} S_{\mathrm{Xo03534}}$ colR $R_{\mathrm{X} 003535}$ were known to control AvrXa21 activity and functions of $\operatorname{col} S_{\mathrm{X003762}} / \mathrm{col} R_{\mathrm{Xo03763}}$ were unknown in Xoo. To characterize the relationship between $r p f$ and colS/colR genes, expression of $\operatorname{col} / \mathrm{col} R$ genes in Rpf mutants of Xoo were analyzed with quantitative reverse transcription PCR (qRT-PCR). Expressions of all three colS/colR genes increased in the rpfF mutant in which DSF synthesis is defective. Expression of $\mathrm{col} \mathrm{S}_{\mathrm{XOO1207}} / \mathrm{col}$ $R_{\mathrm{XOO1208}}, \boldsymbol{c o l} S_{\mathrm{XO03534}} / \mathrm{col} \boldsymbol{R}_{\mathrm{X} 003535}$ and $\mathrm{col} S_{\mathrm{XOO3762}} / \mathrm{col} R_{\mathrm{XO03763}}$ increased 2, 2-7, 3-13 folds respectively. Expression of $\operatorname{col} S_{\mathrm{XOO3534}}$ and $\mathrm{col} \mathrm{S}_{\mathrm{XO03762}}$ also increased 2-4 folds in the $r p f G$ mutant in which the signal from DSF is no longer transferred to down-stream. Expression of the other colS/colR genes was not significantly changed in the $r p f G$ mutant compared to the wild type. Since RpfF and RpfG are responsible for DSF synthesis and signal transfer from DSF to down-stream to regulate virulence gene expression, these results suggest that the DSF and DSF-mediated signal regulate negatively three colS/colR genes in Xoo.

Keywords : ColS/ColR, Rpf, virulence regulation, Xanthomonas oryzae pv. oryzae

Plant pathogenic bacteria must be virulent and able to suppress host resistance to cause a disease on host plant. As bacterial two-component system (TCS), which perceives

*Corresponding author.

Phone) +82-43-261-2554, FAX) +82-43-271-4414

E-mail)jscha@cbnu.ac.kr outside signals and regulates responses inside bacterial cell, $r p f C / r p f G$ and $c o l S_{\mathrm{XOO1207}} / \mathrm{colR}_{\mathrm{XOO1208}}$ are required for virulence of Xanthomonas oryzae pv. oryzae (Xoo) (Slater et al., 2000; Subramoni et al., 2012). The Rpf (regulation of pathogenicity factors) system is known to regulate virulence by the cell-cell communication in $X$. campestris pv. campestris (Xcc) (Barber et al., 1997; He et al., 2007; Slater et al., 2000; Tang et al., 1991). Among rpf genes that were identified as a cluster (rpfA-I) (Tang et al., 1991), $\mathrm{RpfF}$ are responsible for diffusible signal factor (DSF) production (Barber et al., 1997; Wang et al., 2004), and RpfC and RpfG comprise a two-component system, which senses the DSF signal and transfers it to signal cascades involved in virulence (Slater et al., 2000). Virulence factor production and biofilm dispersal are controlled by cyclic di-GMP and Clp, which are on downstream of RpfG (He et al., 2007; Ryan et al., 2007). The $r p f$ genes and functions of the core $r p f$ genes, $r p f B, r p f C, r p f F, r p f G$, are well conserved in Xoo (Chatterjee and Sonti, 2002; Jeong et al., 2008).

The colS/colR genes, which encode a two-component system, were originally identified from the root-colonizing bacterium Pseudomonas fluorescens and found to be involved in the capacity of the bacterium to colonize plant roots (Dekkers et al., 1998). Subsequently, colS/colR genes were reported to regulate different biological responses to transposition of transposon and various stresses including phenol and heavy metals (Hu and Zhao, 2007; Kivistik et al., 2006). The cols/colR genes are required for virulence of several important plant pathogens including Xoo (Subramoni et al., 2012; Yan and Wang, 2011; Zhang et al., 2008).

Mutation of $\mathrm{colS}_{\mathrm{XOO1207}} / \mathrm{col}_{\mathrm{XOO1208}}$ decreased virulence of Xoo. These mutations also caused growth defect in iron-limiting condition and deficiency in elicitation of hypersensitive response on non-host tomato (Subramoni et al., 2012). Another colS/colR genes, $\operatorname{col} S_{\mathrm{XoO} 3534}(\mathrm{raxH}) /$ $\operatorname{col}_{\mathrm{XOO3535}}(\operatorname{rax} R)$, were known to control avrXa21 activity 
in Xoo pXO99A (Burdman et al., 2004; Lee et al., 2008). These previously published results indicate two virulence regulation systems, Rpf and ColS/ColR, control virulence in Xoo. To characterize the relationship between $r p f$ and colS/colR genes for virulence regulation, expression of colS/colR genes in Rpf mutants of Xoo were analyzed with quantitative reverse transcription PCR (qRT-PCR).

Three cols/colR genes are conserved in the important plant pathogens. In Xoo KACC10331 genome, three colS/ colR genes, col $S_{\mathrm{XOO1207}} / \mathrm{col}_{\mathrm{XOO1208}}, \mathrm{col} S_{\mathrm{XOO} 3534} / \operatorname{col}_{\mathrm{XO03535}}$ and $c o l S_{\mathrm{XOO3762}} / \mathrm{col}_{\mathrm{X003763}}$, have been annotated (Lee et al., 2005). Based on literature and homologous gene search, the three colS/colR genes were identified to be well conserved in Xcc 8004 (a black rot pathogen of cabbage) and X. axonopodis pv. citri (Xac) 306 (a citrus canker pathogen of citrus) (Table 1). Nucleotide identity between the $\mathrm{colS} / \mathrm{col} R$ genes of Xoo KACC10331 and Xac 306 or Xcc 8004 were all more than $90 \%$. E-value obtained by BlastN between each $\mathrm{colS} / \mathrm{colR}$ genes of Xoo KACC10331 and corresponding genes in either Xac 306 or Xcc 8004 were all 0.0. These indicate that nucleotide sequences of the three colS/ $\operatorname{col} R$ genes are well conserved in the three pathogens.

The $\operatorname{col} S_{\mathrm{XC} \_1050} /$ col $_{\mathrm{XC} \_1049}$, col $S_{\mathrm{XAC} 3249} / \operatorname{col}_{\mathrm{XAC} 3250}$ and $c o l S_{\mathrm{XOO1207}} / \mathrm{col}_{\mathrm{XOO1208}}$ are known to be all required for virulence in each pathogen. Zhang et al. (2008) showed that $c o l S_{\mathrm{XC} \_1050} /{ }$ oll $R_{\mathrm{XC} \_1049}$ was involved in virulence, hypersensitive response and tolerance to various stresses in $\mathrm{Xcc} 8004$. The $\operatorname{col} S_{\mathrm{XC}_{-} 1050} / \mathrm{col} R_{\mathrm{XC} \_1049}$ positively regulated expression of $h r p C$ and $h r p E$ operons and expression of col $S_{\mathrm{XC} \_1050} / c_{0}$ l $R_{\mathrm{XC}_{-} 1049}$ were not controlled by the key $h r p$ regulators HrpG and HrpX. Yan and Wang (2011) showed that $\operatorname{col} S_{\mathrm{XAC} 3249} /$ colR $_{\mathrm{XAC} 3250}$ were critical for $X$. citri subsp. citri (Xac) in virulence, growth in planta, biofilm formation, catalase activity, LPS production, and resistance to environmental stress. In Xoo, colS $\mathrm{XOO1207}_{1} / \mathrm{col}_{\mathrm{XOO1208}}$ were required for virulence and hypersensitive response on nonhost plant (Subramoni et al., 2012).

Rpf Mutants, complementation and qRT-PCR. Wild type strain, Xoo KACC10859, two Rpf mutant strains, CBNUXO05 (rpfF::EZ-Tn5), CBNUXO06 (rpfG::EZ-Tn5) and complement strains, CBNUXO05C (rpfF::EZ-Tn5/ pVSP61-mcs-sp::rpfF), CBNUXO06C (rpfG::EZ-Tn5/ pVSP61-mcs-sp::rpfG) were used in this study (Table 2). Mutants of rpf genes and their biological characteristics including DSF production were published previously (He et al., 2010; Jeong et al., 2008). To complement the mutants, cloning vector, $p$ VSP61-mes-sp was constructed by modification of pVSP61, which is very stable plasmid vector in Pseudomonads (Loper and Lindow, 1994). Polylinker of pUC9 in pVSP61 was replaced with polylinker of pUC19 at EcoRI - HindIII sites to increase availability of cloning sites (pVSP61-mcs). Spectinomycin resistance gene was inserted into BglII site in $\mathrm{Km}^{\mathrm{R}}$ gene of the pVSP61-mcs resulting in Kanamycin resistance inactivated and Spectinomycin resistance (pVSP61-mcs-sp).

For complementation of CBNUXO05 ( $r p f F:: E Z-T n 5)$, DNA fragments containing $r p f F$ including 200 bp of its 5 ' region were cloned into HindIII-KpnI sites with PCR products amplified with primers, rpfF-kpn1-F: 5' AGTGGTACCACATCAGCCGGCGTCAAGC 3' and rpfFhind3-R: 5' AGTAAGCTTCCGTGAATGCGGGACGCG 3' (pVSP61-mcs-sp::rpfF). For complementation of CBNUXO06 (rpfG::EZ-Tn5), DNA fragments containing $r p f G$ including 386 bp of its 5 ' region were cloned into

Table 1. Conservation of colS/colR genes in Xanthomonas oryzae pv. oryzae KACC10331, Xanthomonas axonopodis pv. citri 306 and Xanthomonas campestris pv. campestris $8004^{\mathrm{a}}$

\begin{tabular}{|c|c|c|c|c|c|}
\hline \multicolumn{2}{|c|}{ Хоo KACC10331 } & \multicolumn{2}{|r|}{ Xac 306} & \multicolumn{2}{|c|}{ Xcc 8004} \\
\hline Gene/Gene ID & Function & Gene/Gene ID & Function & Gene/Gene ID & Function \\
\hline $\begin{array}{l}\text { cols, XOO1207/ } \\
\text { colR, XOO1208 }\end{array}$ & $\begin{array}{l}\text { Virulence, HR on non-host, } \\
\text { growth in iron-limiting; } \\
\text { Subramoni et al. (2012) }\end{array}$ & $\begin{array}{l}\text { cols, XAC3249/ } \\
\text { colR, XAC } 3250\end{array}$ & $\begin{array}{l}\text { Virulence, biofilm forma- } \\
\text { tion, resistance to envi- } \\
\text { ronmental stress; Yan \& } \\
\text { Wang (2011) }\end{array}$ & $\begin{array}{l}\mathrm{XC} \_1050 / \\
\mathrm{XC} \_1049\end{array}$ & $\begin{array}{l}\text { Virulence, HR, toler- } \\
\text { ance to various stress; } \\
\text { Zhang et al. (2008) }\end{array}$ \\
\hline $\begin{array}{l}\operatorname{col} S(\operatorname{rax} H), \\
\mathrm{XOO} 3534 / \operatorname{col} R \\
(\operatorname{rax} R), \mathrm{XOO} 3535\end{array}$ & $\begin{array}{l}\text { AvrXa21; Burdman et al. } \\
\text { (2004), Lee et al. (2008) }\end{array}$ & $\begin{array}{l}\text { cols, XAC1222/ } \\
\text { colR, XAC1221 }\end{array}$ & unknown & $\begin{array}{l}\mathrm{XC} \_3125 / \\
\mathrm{XC} \_3126\end{array}$ & unknown \\
\hline $\begin{array}{l}\text { cols, } \mathrm{XOO} 3762 / \\
\text { colk, } \mathrm{XOO} 3763\end{array}$ & unknown & $\begin{array}{l}\text { cols, XAC0835/ } \\
\text { colR, XAC0834 }\end{array}$ & unknown & $\begin{array}{l}\mathrm{XC} \_3451 / \\
\mathrm{XC} \_3452\end{array}$ & unknown \\
\hline
\end{tabular}

${ }^{a}$ Nucleotide identity covered regions between the colS/colR genes of Xoo KACC 10331 and Xac 306 or Xcc 8004 were more than 90\%. Evalues between $\mathrm{col} / \mathrm{s} / \mathrm{colR}$ genes of Xoo KACC10331 and corresponding genes in either Xac 306 or Xcc8004 were all 0.0. 
Table 2. Bacterial strains and plasmids used in this study

\begin{tabular}{|c|c|c|}
\hline Strain/Plasmid & Relevant Characteristics* & Source \\
\hline \multicolumn{3}{|c|}{ Xanthomonas oryzae pv. oryzae } \\
\hline KACC10859 & Wild-type, $\mathrm{Cp}^{\mathrm{r}}$ & RDA, South Korea \\
\hline CBNOXOO5 & $r p f F:: \mathrm{EZ}-\mathrm{Tn} 5, \mathrm{Km}^{\mathrm{r}}$ & Jeong et al., 2008; He et al., 2010 \\
\hline CBNUXOO6 & $r p f G:: \mathrm{EZ}-\mathrm{Tn} 5, \mathrm{Km}^{\mathrm{r}}$ & Jeong et al., 2008; He et al., 2010 \\
\hline CBNUXOO5C & CBNUXOO5/pVSP61-mcs-sp::rpfF, $\mathrm{Km}^{\mathrm{r}}, \mathrm{Sp}^{\mathrm{r}}$ & This study \\
\hline CBNUXOO6C & CBNUXOO6/pVSP61-mcs-sp::rpfG, $\mathrm{Km}^{\mathrm{r}}, \mathrm{Sp}^{\mathrm{r}}$ & This study \\
\hline pVSP61 & $\mathrm{Km}^{\mathrm{r}}$ & Loper and Lindow, 1994 \\
\hline pVSP61-mcs-sp & pVSP61::MCS of Puc19::Sp ${ }^{r}, \mathrm{Sp}^{\mathrm{r}}$ & This study \\
\hline pVSP61-mcs-sp::rpfF & pVSP61-mcs-sp::rpfF, $\mathrm{Sp}^{\mathrm{r}}$ & This study \\
\hline pVSP61-mcs-sp::rpfG & pVSP61-mcs-sp::rpfF, $\mathrm{Sp}^{\mathrm{r}}$ & This study \\
\hline
\end{tabular}

${ }^{*} \mathrm{Cp}^{\mathrm{r}}$ : cephalexin resistance, $\mathrm{Km}^{\mathrm{r}}$ : kanamycin resistance, $\mathrm{Sp}^{\mathrm{r}}$ : spectinomycin resistance.

HindIII-BamHI sites with PCR products amplified with primers, rpfG-hind3-F: 5' AGTAAGCTTAAGGACGGCGGTGACGACG 3' and rpfG-bamh1-R: 5'AGTGGATCCATCACGCAGCTGACCAGGCG 3' (pVSP61mes-sp::rpfG). Plasmid pVSP61-mes-sp::rpfF and pVSP61-mcs-sp::rpfG were transformed into CBNUXO05 (rpfF::EZ-Tn5) and CBNUXO06 (rpfG::EZ-Tn5) with standard electroporation protocol. Mutants and its complementation strains were confirmed by PCR genotyping (supplementary Fig. 1).

RNA was isolated from the bacterial cells cultured in hrp-inducing culture conditions (Seo et al., 2008). Wild type, mutant and complement strains were cultured in PS broth (peptone $10 \mathrm{~g}$, sucrose $10 \mathrm{~g}$, L-glutamic acid $1 \mathrm{~g}$ per $1 \mathrm{~L}, \mathrm{pH} 7.0$ ) to $\mathrm{OD}_{600}=0.2$ and the bacterial cells were washed twice with sterilized water and transferred to Xom2 medium (0.18\% xylose, $670 \mathrm{uM} \mathrm{L-methionine,} 10 \mathrm{mM} \mathrm{L-}$ glutamic acid, $14.7 \mathrm{mM}$ potassium phosphate (monobasic), $40 \mu \mathrm{M}$ manganese sulfate, $240 \mu \mathrm{M}$ Fe(III) EDTA, $5 \mathrm{mM}$ magnesium chloride per $1 \mathrm{~L}, \mathrm{pH}$ 6.5). After $18 \mathrm{~h}$ further culture, bacterial cells were harvested for RNA isolation. Total RNA of each strains was isolated using the RNeasy ${ }^{\circledR}$ Mini kit (Qiagen, Valencia, CA), and residual genomic DNA was removed using the RNase-Free DNase Set (Qiagen, Valencia, CA) and RNeasy ${ }^{\circledR}$ MinElute ${ }^{\mathrm{TM}}$ Cleanup kit (Qiagen, Valencia, CA), according to the manufacturer's instructions. DNase I-treated total RNA was measured with a Nano Drop 2000 (Thermo scientific, Wilmington, USA) and $1 \mu \mathrm{g}$ total RNA was used to synthesize cDNA. cDNA was generated using SuperScript ${ }^{\circledR}$ III First-Strand Synthesis System for RT-PCR (Invitrogen, Carlsbad, CA), following the manufacturer's protocol. After the reaction, samples were diluted with $190 \mu \mathrm{L}$ of distilled water and used as a template cDNA for qRT-PCR. qRT-PCR experiments were performed by Rotor-gene Q (Qiagen, Valencia, CA) and using $2 \times$ Rotor-gene ${ }^{\mathrm{TM}} \mathrm{SYBR}^{\circledR}$ Green PCR kit (Qiagen, Valencia, CA) containing $1 \mu \mathrm{L}$ of diluted cDNA. The constitutively expressed $r r s A$ gene coding $16 \mathrm{~S}$ rRNA was used as an internal control for relative quantification (Subramoni et al., 2012). Gene-specific primers designed and their amplification efficiency was checked with RNA isolated from the wild type strain. Primers with $\mathrm{R}^{2}>0.99$ and slope 3.2-3.6 were used (Table 3). qRT-PCR condition included initial heating for $10 \mathrm{~min}$ at $95^{\circ} \mathrm{C}$, followed by 40 cycles of PCR $\left(95^{\circ} \mathrm{C}, 15 \mathrm{~s} ; 58^{\circ} \mathrm{C}, 30 \mathrm{~s} ; 72^{\circ} \mathrm{C} 30 \mathrm{~s}\right)$. To analyze obtained results, $\Delta \Delta \mathrm{Ct}$ method was used and quantification results were calculated.

Expression of $r p f F$ and $r p f G$ genes in its mutant and complement strains. Expression of $r p f F$ and $r p f G$ in its mutants and complement strains was checked to confirm the mutation and complementation works. The $r p f F$ and rpfG was expressed about 11 fold and 100 fold less in its mutant strain, CBNUXO05 (rpfF::EZ-Tn5) and CBNUXO06 (rpfG::EZ-Tn5) than in the wild type strain respectively (Table 4). Expression of $r p f F$ in the complement strain, CBNUXO05C (rpfF::EZ-Tn5/pVSP61-mcssp::rpfF) was similar to the wild type strain while $r p f G$ was expressed in the complemented strain, CBNUXO06C (rpfG::EZ-Tn5/pVSP61-mcs-sp::rpfG), was about 4 fold higher than in the wild type (Table 4). Forward and reverse primer of $r p f F$ - and $r p f G$-specific primers were designed from outside of both end of EZ-Tn 5 insertion site. Since EZ-Tn5 contains transcription terminator, expression level of the two genes must be near 0 in the mutant strains. When the PCR products were checked by gel electrophoresis after qRT-PCR, no proper-size band or very faint band were appeared in triplicate lanes. Although results of qRTPCR showed the low expression level of $r p f F$ and $r p f G$ in its mutant strains, these results indicate that $\mathrm{RpfF}$ and $\mathrm{RpfG}$ 
Table 3. Primers used for quantitative RT-PCR

\begin{tabular}{|c|c|c|c|}
\hline Gene ID/Gene & Product & Sequence $\left(5^{\prime}-3^{\prime}\right)$ & Source \\
\hline $\operatorname{rrs} A$ & $16 \mathrm{~S}$ ribosomal RNA & $\begin{array}{l}\text { F: CCCTAAACGATGCGAACTGGATGT } \\
\text { R: AGTTTCAGTCTTGCGACCGTACTC }\end{array}$ & Subramoni et al., 2012 \\
\hline$r p f F$, XOO2869 & $\mathrm{RpfF}$ & $\begin{array}{l}\text { F: GAGCTGCCACACCATCATCG } \\
\text { R: GGCGGAGTACAGATTGCCTTCT }\end{array}$ & This study \\
\hline rpfG, XOO2871 & Response regulator & $\begin{array}{l}\text { F: TTTCATCACGCTCATCTCGTCGT } \\
\text { R: TCTCGAACGCATGTCTCATGTGG }\end{array}$ & This study \\
\hline cols, XOO1207 & Two-component system sensor protein & $\begin{array}{l}\text { F: TACAAGCGCAAACAGAATCG } \\
\text { R: TTGTTACGGGGTCCGAATTA }\end{array}$ & This study \\
\hline colR, XOO1208 & Two-component system regulatory protein & $\begin{array}{l}\text { F: AGCTTGTTGTCCAGCGAGTC } \\
\text { R: ATCGTGCTCGATCTCAACCT }\end{array}$ & This study \\
\hline cols, XOO3534 & $\begin{array}{l}\text { Two-component system sensor protein, } \\
\text { RaxH }\end{array}$ & $\begin{array}{l}\text { F: GATAGCGAGATGCGGATGAT } \\
\text { R: ATCTGCAACTGGTCCTGGAG }\end{array}$ & This study \\
\hline colR, XOO3535 & $\begin{array}{l}\text { Two-component system regulatory protein, } \\
\text { RaxR }\end{array}$ & $\begin{array}{l}\text { F: AAGGATCAGGGCGTCGTAGT } \\
\text { R: GCTGCTGGTCATTGAAGACA }\end{array}$ & This study \\
\hline cols, XOO3762 & Two-component system sensor protein & $\begin{array}{l}\text { F: ACGAACGACACCAGATACCC } \\
\text { R: CTCACGGTAGCGTTGCCTAT }\end{array}$ & This study \\
\hline colR, XOO3763 & Two-component system regulatory protein & $\begin{array}{l}\text { F: ACGGCTTGGTCAGGTAGTCATC } \\
\text { R: CAAGTCCACGCCGGTGTTGAT }\end{array}$ & This study \\
\hline
\end{tabular}

Table 4. Effect of Xanthomonas oryzae pv. oryzae KACC10859 rpfF and $r p f G$ mutations on expression of expression of colS/colR, $r p f F$ and $r p f G$

\begin{tabular}{|c|c|c|c|c|c|c|c|c|}
\hline \multirow{2}{*}{ strain } & \multicolumn{8}{|c|}{ Fold expression change \pm standard deviation* } \\
\hline & XOO1207 & XOO1208 & XOO3534 & XOO3535 & XOO3762 & XOO3763 & $r p f F$ & $r p f G$ \\
\hline CBNUXO05 (rpfF::EZ-Tn5) & $2.11 \pm 0.14^{\mathrm{a}^{* *}}$ & $1.90 \pm 0.13^{\mathrm{a}}$ & $7.53 \pm 0.87^{\mathrm{a}}$ & $2.95 \pm 0.11^{\mathrm{a}}$ & $13.31 \pm 0.55^{\mathrm{a}}$ & $3.45 \pm 0.20^{\mathrm{a}}$ & $0.09 \pm 0.01^{\mathrm{b}}$ & $1.44 \pm 0.15^{\mathrm{b}}$ \\
\hline $\begin{array}{l}\text { CBNUXO05C (rpfF::EZ-Tn5/ } \\
\text { pVSP61-mcs-sp::rpfF) }\end{array}$ & $1.23 \pm 0.04^{\mathrm{b}}$ & $1.06 \pm 0.09^{\mathrm{b}}$ & $1.25 \pm 0.15^{\mathrm{c}}$ & $1.12 \pm 0.15^{\mathrm{c}}$ & $1.58 \pm 0.15^{\mathrm{bc}}$ & $1.32 \pm 0.23^{\mathrm{b}}$ & $1.06 \pm 0.13^{\mathrm{a}}$ & $0.93 \pm 0.12^{\mathrm{c}}$ \\
\hline CBNUXO06 (rpfG::EZ-Tn5) & $1.04 \pm 0.05^{\mathrm{b}}$ & $1.12 \pm 0.13^{b}$ & $4.24 \pm 0.04^{\mathrm{b}}$ & $1.78 \pm 0.12^{\mathrm{b}}$ & $2.13 \pm 0.13^{\mathrm{b}}$ & $1.34 \pm 0.09^{\mathrm{b}}$ & $0.92 \pm 0.06^{\mathrm{a}}$ & $0.01 \pm 0^{\mathrm{d}}$ \\
\hline $\begin{array}{l}\text { CBNUXO06C (rpfG::EZ-Tn5/ } \\
\text { pVSP61-mcs-sp::rpfG) }\end{array}$ & $1.02 \pm 0.08^{\mathrm{b}}$ & $1.15 \pm 0.02^{\mathrm{b}}$ & $1.33 \pm 0.04^{\mathrm{c}}$ & $1.09 \pm 0.04^{\mathrm{c}}$ & $1.21 \pm 0.04^{\mathrm{c}}$ & $1.03 \pm 0.01^{\mathrm{b}}$ & $0.88 \pm 0.05^{\mathrm{a}}$ & $4.88 \pm 0.19^{\mathrm{a}}$ \\
\hline
\end{tabular}

*The fold expression change (mutant or complemented mutant/wild type) was calculated using $2^{-\Delta \Delta C t}$ with three replicates.

**Means with the same letter are not significantly different by Turkey's HSD test using SAS 9.2.

were non-functional in the respective mutant while those in the complemented strains were similar to the wild-type strain.

Expression of cols/colR genes was increased in rpfF and $r p f G$ mutants. Expressions of $c o l S_{\mathrm{XOO1207}} / \mathrm{col}_{\mathrm{XOO1208}}$ about 2 fold increased in CBNUXO05 (rpfF::EZ-Tn5), while expression of both genes was not different in CBNUXO06 (rpfG::EZ-Tn5) (Table 4). Although we do not know biological significant of 2 fold increase of this two-component system in the $r p f F$ mutant yet, qRT-PCR results suggest that expression $\mathrm{col} S_{\mathrm{XOO1207}} / \mathrm{col} \mathrm{R}_{\mathrm{XOO1208}}$ is influenced directly by DSF rather than signal through RpfG. In Rpf virulence regulation system, $\mathrm{RpfF}$ are responsible for the production of DSF (Barber et al., 1997; Wang et al., 2004) and RpfG transfers signal from RpfC that sense the DSF signal to its downstream (He et al., 2007; Ryan et al., 2007; Slater et al., 2000).

Expressions of $\operatorname{col} S_{\mathrm{X003534}}(\mathrm{raxH}) / \mathrm{colR}_{\mathrm{X003535}}(\operatorname{raxR})$ highly increased in both $r p f F$ and $r p f G$ mutants (Table 4). Coding sensor gene, col $S_{\mathrm{X003534}}$ was expressed about 7 and 4 fold higher in the $r p f F$ mutant and the $r p f G$ mutant, respectively, while its cognate coding regulator gene, col-

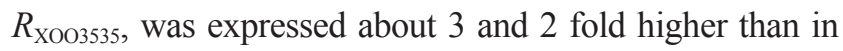
the wild type. These results suggest that DSF and signal from DSF through RpfG regulate negatively the expression of $\mathrm{col} S_{\mathrm{XOO} 3534} / \mathrm{col} R_{\mathrm{XOO} 3535}$ in the wild strain. Since $\mathrm{col}$ $S_{\mathrm{X003534}} / \mathrm{colR}_{\mathrm{XO03535}}$ has been proved to control of avrXa21 
(Lee et al., 2008; Burdman et al., 2004), DSF may suppress avirulence activity by suppression of the expression of two genes for promoting virulence.

Expression of $\mathrm{colS}_{\mathrm{X003762}} / \mathrm{colR}_{\mathrm{XOO3763}}$ was increased about 13 and 3 folds, respectively in CBNUXO05 ( $r p f F:$ EZ$\mathrm{Tn} 5)$ and expression of col $S_{\mathrm{XOO} 3762}$ was also increased about 2 folds in CBNUXO06 (rpfG::EZ-Tn5) comparing to wild type strain and expression of its cognate regulator, $\operatorname{col}_{\mathrm{X003763}}$, was not changed significantly in CBNUXO06 ( $r p f G:: E Z-T n 5)$. These results suggest DSF regulates negatively this two-component system in the wild type. Biological function of positive regulation of $c$ ol $S_{\mathrm{XOO} 3762}$ is not clear, since function of $\mathrm{col} S_{\mathrm{XOO3762}} / \mathrm{col}_{\mathrm{XOO} 3763}$ is not known.

In this study, expression of three two-component system genes, two of them are known to control virulence and avirulence, increased significantly in the $r p f F$ mutant, CBNUXO05 (rpfF::EZ-Tn5), and expression of col $S_{\mathrm{Xo0} 3534}$ $(\mathrm{raxH}) / \mathrm{colR}_{\mathrm{XOO3535}}(\mathrm{raxR})$ and $\mathrm{col} S_{\mathrm{XOO3762}}$ also increased in the $r p f G$ mutant, CBNUXO06 (rpfG::EZ-Tn5). Overall these results indicate DSF and downstream of DSF signal regulate negatively three $\mathrm{colS} / \mathrm{colR}$ genes in Xoo. Although biological function of these regulations by DSF is unclear yet and further detail work on this area is needed, we think that these regulations may be a part of hierarchal control of pathogenicity, which is needed for pathogen to successfully cause a disease on host plant.

\section{Acknowledgement}

This work was supported by a research grant from Chungbuk National University and Pusan National University Research Grant in 2011.

\section{References}

Barber, C. E., Tang, J. L., Feng, J. X., Pan, M. Q., Wilson, T. J. G., Slater, H., Dow, J. M., Williams, P. and Daniels, M. J. 1997. A novel regulatory system required for pathogenicity of Xanthomonas campestris is mediated by a small diffusible signal molecule. Mol. Microbiol. 24:555-566.

Burdman, S., Y. Shen, S.-W. Lee, Q. Xue, and P. Ronald. 2004. RaxH/RaxR: a two-component regulatory system in Xanthomonas oryzae pv. oryzae required for AvrXa21 activity. Mol. Plant-Microbe Interact. 17:602-612.

Chatterjee, S. and Sonti, R. 2002. $r p F$ mutants of Xanthomonas oryzae pv. oryzae are deficient for virulence and growth under low iron conditions. Mol. Plant-Microbe Interact. 15:463471.

Dekkers, L., Bloemendaal, C. J., Weger, L., Wijffelman, C., Spaink, H. and Lugtenberg, B. J. 1998. A two-component system plays an important role in the root-colonizing ability of Pseudomonas fluorescens strain WCS365. Mol PlantMicrobe Interact. 11:45-56.

He, Y.-W., Ng, A. Y.-J., Xu, M., Lin, K., Wang, L.-H., Dong, Y.H. and Zhang, L.-H. 2007. Xanthomonas campestris cellcell communication involves a putative nucleotide receptor protein Clp and a hierarchical signalling network. Mol. Microbiol. 64:281-292.

He, Y.-W., Wu, J., Cha, J.-S. and Zhang, L.-H. 2010. Rice bacterial blight pathogen Xanthomonas oryzae pv. oryzae produces multiple DSF-family signals in regulation virulence factor production. BMC Microbiol. 10:187.

$\mathrm{Hu}$, N. and Zhao, B. 2007. Key genes involved in heavy-meral resistance in Pseudomonas putida CD2. FEMS Microbial. Lett. 267:17-22.

Jeong, K. S., Lee, S. E., Han, J. W., Yang, S. U., Lee, B. M., Noh, T. H. and Cha, J. S. 2008. Virulence reduction and differing regulation of virulence genes in rpf mutants of Xanthomonas oryzae pv. oryzae. Plant Pathol. J. 24:143-151.

Kivistik, P. A., Putrins, M., Puvi, K., Ilves, H., Kivsaar, M. and Horak, R. 2006. The ColR two-component system regulates membrane functions and protects Pseudomonas putida against phenol. J. Bacteriol. 188:8109-8117.

Loper, J. E and Lindow, S. E. 1994. A biological sensor for iron availability to bacteria in their habitats in their plant surfaces. Appl. Environ. Microbiol. 60:1934-1941.

Lee, N. M., Park, Y. J., Park, D. S., Kang, H. W., Kim, J. G., Song, E. S., Park, I. C., Yoon, U. H., Hahn, J. H., Koo, B. S., Lee, G. B., Kim, H., Park, H. S., Yoon, K. O., Kim, J. H., Jung, C. H., Koh, N. H., Seo, J. S. and Go, S. J. 2005. The genome sequence of Xanthomonas oryzae pathover oryzae KACC10331, the bacterial blight pathogen of rice. Nucleic Acids Res. 33:577-586.

Lee, S.-W., Jeong, K.-S., Han, S.-W., Lee, S.-E., Phee, B.-K, Hahn, T.-R. and Ronald, P. 2008. The Xanthomonas oryzae pv. oryzae PhoPQ two-component system is required for AvrXA21 Activity, hrp $G$ expression, and virulence. $J$. Bacteriol. 190:2183-2197.

Ryan, R. P., Fouhy, Y., Lucey, J. F., Jiang, B.-L., He, Y.-Q., Feng, J.-X., Tang, J.-L. and Dow, J. M. 2007. Cyclic di-GMP signalling in the virulence and environmental adaptation of Xanthomonas campestris. Mol. Microbiol. 63:429-442.

Seo, Y.-S., Sriariyanun, M., Wang, L., Pfeiff, J., Phetsom, J., Lin, Y., Jung, K.-H., Chou, H. H., Bogdanove, A. and Ronald, P. 2008. A two-genome microarray for the rice pathogens Xanthomonas oryzae pv. oryzae and X. oryzae pv. oryzicola and its use in the discovery of a difference in their regulation of hrp genes. BMC Microbiol. 8:99.

Slater, H., Alvarez-Morales, A., Barber, C. E., Daniels, M. J. and Dow, J. M. 2000. A two-component system involving an HDGYP domain protein links cell-cell signalling to pathogenicity gene expression in Xanthomonas campestris. Mol. Microbiol. 38:986-1003.

Subramoni, S., Pandey, A., Priya, M. R. V., Patel, H. K. and Sonti, R. 2012. The ColRS system of Xanthomonas oryzae pv. 
oryzae is required for virulence and growth in iron-limiting conditions. Mol. Plant Pathol. 13:690-703.

Tang, J. L., Liu, Y. N., Barber, C. E., Dow, J. M., Wootton, J. C. and Daniels, M. J. 1991. Genetic and molecular analysis of a cluster of $r p f$ genes involved in positive regulation of synthesis of extracellular enzymes and polysaccharide in Xanthomonas campestris pathovar campestris. Mol. Gen. Genet. 226:409-417.

Wang, L. H., He, Y. W., Gao, Y. F., Wu, J. E., Dong, Y. H., He, C. Z., et al. 2004. A bacterial cell-cell communication signal with cross-kingdom structural analogues. Mol. Microbiol. 51: 903-912.
Yan, Q. and Wang, N. 2011. The ColR/ColS two-component system plays multiple roles in the pathogenicity of the citrus canker pathogen Xanthomonas citir subsp. citiri. J. Bactriol. 193:1590-1599.

Zhang, S. S., He, Y. Q., Xu, L. M., Chen, B. W., Jiang, B. L., Liao, J., Cao, J. R., Liu, D., Huang, Y. Q., Liang, X. X., Tang, D. J., Lu, G. T. and Tang, J. L. 2008. A putative colR(XC1049)-colS(XC1050) two-component signal transduction system of Xanthomonas campestris positively regulates $h r p C$ and $h r p E$ operons and is involved in virulence, the hypersensitive response and tolerance to various stresses. Res. Microbiol. 159:569-578. 